\title{
The Courts and the Restitution of Indigenous Territories in Malaysia
}

\author{
Yogeswaran Subramaniam \& Colin Nicholas*
}

\begin{abstract}
Despite enjoying distinct and privileged constitutional statuses, the Indigenous minorities of Malaysia, namely, the natives of Sabah, natives of Sarawak and the Peninsular Malaysia Orang Asli continue to endure dispossession from their customary lands, territories and resources. In response, these groups have resorted to seeking justice in the domestic courts to some degree of success. Over the last two decades, the Malaysian judiciary has applied the constitutional provisions and developed the common law to recognise and protect Indigenous land and resource rights beyond the literal confines of the written law. This article focuses on the effectiveness of the Malaysian courts in delivering the preferred remedy of Indigenous communities for land and resource issues, specifically, the restitution or return of traditional areas to these communities. Despite the Courts' recognition and to a limited extent, return of Indigenous lands and resources beyond that conferred upon by the executive and legislative arms of government, it is contended that the utilisation of the judicial process is a potentially slow, costly, incongruous and unpredictable process that may also not necessarily be free from the influence of the domestic political and policy debates surrounding the return of Indigenous lands, territories and resources.
\end{abstract}

\section{Introduction}

Access to remedies and redress for land rights constitute an important element of indigenous peoples' recourse to litigation. The right of indigenous peoples to redress in respect of their lands, territories and resources has been acknowledged in international law. Article 28 of the

\footnotetext{
Yogeswaran Subramaniam is an Advocate and Solicitor in Malaysia and holds a PhD from the University of New South Wales for his research on Orang Asli land rights. In addition to publishing extensively on Orang Asli land and resource rights, he has acted as legal counsel in a number of landmark indigenous land rights decisions in Malaysia. Colin Nicholas is the founder and coordinator of the Centre for Orang Asli Concerns (COAC). He received a PhD from the University of Malaya on the topic of Orang Asli: Politics, Development and Identity, and has authored several academic articles and books on Orang Asli issues. He has provided expert evidence in a number of leading Orang Asli cases. The law stated in this article is current as on 1 October 2017. Yogeswaran Subramaniam is an Advocate and Solicitor in Malaysia and holds a PhD from the University of New South Wales for his research on Orang Asli land rights. In addition to publishing extensively on Orang Asli land and resource rights, he has acted as legal counsel in a number of landmark indigenous land rights decisions in Malaysia.
}

2007 United Nations Declaration on the Rights of Indigenous Peoples (UNDRIP) ${ }^{1}$ provides as follows:

Indigenous peoples have the right to redress, by means that can include restitution or, when this is not possible, just, fair and equitable compensation, for the lands, territories and resources which they have traditionally owned or otherwise occupied or used, and which have been confiscated, taken, occupied, used or damaged without their free, prior and informed consent.

This provision represents an important element of the declaration, which was forged over more than a decade and in consultation with worldwide indigenous representation. It underscores the significance of the inextricable link that indigenous communities commonly have with their traditional territorial space and perhaps more relevant to this article, the preference for restitution of indigenous lands, territories and resources as a remedy for past and continuing dispossession.

For the right of restitution to be meaningful in effectively addressing the concern of UN Member States that 'Indigenous peoples have suffered from historic injustices as a result of, inter alia, their colonization and dispossession of their lands, territories and resources', restitution should ideally extend beyond the return of indigenous areas continuously occupied, used or enjoyed to those areas previously occupied, used or enjoyed by aggrieved communities. Unfortunately for most indigenous communities, state acceptance of the restitution of indigenous lands, territories and resources as the favoured mode of legal redress, particularly in respect of lands earlier lost to others and where third party rights have intervened, has been shown to be contentious, or at best an 'ambiguous compromise'. ${ }^{3}$

This article focuses on the potential of the common law as applied by the Malaysian courts to return indigenous lands, territories and resources continuously (until the present or very recently) occupied, used or enjoyed by an indigenous community that have been encroached

1. 2. 3.
GA Res. 61/295, 13 September 2007.

UNDRIP, preambular para. 6 .

For further commentary on the issues surrounding the right to restitution of indigenous land, territory and resource rights under international law, see e.g. J. Gilbert, Indigenous Peoples' Land Rights under International Law: From Victims to Actors (Leiden: Brill, 2nd edn.) (2016), at 147-68; A. Xanthaki, Indigenous Rights and United Nations Standards: Self-Determination, Culture and Land (Cambridge: Cambridge University Press) (2007), at 264-7. 
upon by third parties or taken away by the state. Across Malaysia, many indigenous communities have had recourse to courts to reclaim their fundamental rights over their traditional lands and resources. Utilising common law jurisprudence and considering the special status of indigenous groups shaped during colonial and post-independence constitutional and legal arrangements, the Malaysian judiciary has recognised the legal continuity of pre-existing indigenous customary land and resource rights over the past two decades. Despite not specifically addressing the historical dispossession of lands, territories and resources suffered by Malaysian indigenous communities, this recognition has been instrumental in providing these communities some legal redress for claims of illegal dispossession from their lands, territories and resources beyond the literal confines of the written law. It is hoped that the scenario in Malaysia will inform further inquiries into the utilisation of domestic courts as a redress mechanism for the dispossession of traditional indigenous areas.

After providing the necessary background on the indigenous communities of Malaysia and the salient issues pertaining to their customary territories, this article will synthesise the Malaysian courts' recognition of customary rights relating to lands, territories and resources beyond written law and the remedy of restitution in relation to such recognition. The article will then examine the legal challenges and more generally, the political realities faced by indigenous communities in gaining effective restitution of their customary territories through the Malaysian courts.

\section{Indigenous Customary Territorial Rights in Malaysia: A Contextual Overview}

Geographically, the bulk of the Federation of Malaysia consists of the peninsular land that separates the Straits of Malacca from the South China Sea and most of the northern quarter of the island of Borneo. Peninsular Malaysia consists of eleven states and two federal territories. The Borneo territories are made up of the states of Sabah and Sarawak and a federal territory.

As of July 2017, the population in Malaysia was estimated at 32.0 million $^{4}$ of which around $50.1 \%$ and $11.8 \%$ consisted of ethnic Malays and indigenous groups, respectively. ${ }^{5}$ Ethnic Malays ${ }^{6}$ and other indigenous

4. Department of Statistics, Malaysia Official Portal, <https://www.dosm. gov.my/v1/index.php?r=column/cthemeByCat\&cat=155\&bul_id= a1d1UTFZazd5ajJiRWFHNDduOXFFQT09\&menu_id= LOpheU43NWJwRWVSZkIWdzQ4TIhUUT09> (last visited 6 September 2017).

5. Central Intelligence Agency Library, The World Factbook: East and Southeast Asia: Malaysia <https://www.cia.gov/library/publications/the -world-factbook/geos/my.html> (last visited 1 May 2017).

6. A 'Malay' means a person who professes the religion of Islam, habitually speaks the Malay language, conforms to Malay custom and: (a) was before Merdeka Day (31 August 1957) born in Malaya or Singapore, or groups, meaning, the natives of $\mathrm{Sabah}^{7}$ and natives of Sarawak $^{8}$ and Orang Asli ('aborigine(s)' in the English version of the Federal Constitution) ${ }^{9}$ have been afforded varying degrees of constitutional rights and privileges as a result of the legal arrangements for the protection of those considered to be 'indigenous' or 'native' during the decolonisation process and the formation of the Federation of Malaya in 1957 and subsequently, the Federation of Malaysia (with Sabah and Sarawak) in 1963.

Although the term 'indigenous peoples' is not contained in the Federal Constitution, the natives of Sabah and Sarawak and Peninsular Malaysia Orang Asli have selfidentified as indigenous peoples at international human rights fora and domestically. Additionally, these groups fulfil international criteria for 'indigenous people' under various international human rights documents in that they are individually considered the earliest inhabitants of their respective ecological spaces and collectively constitute a non-dominant and marginalised group in the Federation of Malaysia who have voluntarily perpetuated a cultural distinctiveness compared to dominant society. ${ }^{10}$ Similar to other indigenous peoples internationally, these heterogeneous communities, which have been officially categorised into more than 100 ethnic and sub-ethnic groups, also struggle to maintain the inextricable political, social, economic and cultural link that they possess with their respective and distinctive local spatial niches. This link defines their culture, identity and well-being. Accordingly, the focus of this article will be on the customary territorial rights of these three groups, namely the natives of Sabah, natives of Sarawak and Peninsular Malaysia Orang Asli.

Notwithstanding the provision for equality under Article 8 of the Federal Constitution, Article 153 of the Federal Constitution provides for the Yang Dipertuan Agong ${ }^{11}$ to safeguard the 'special position of ... natives of any of the States of Sabah and Sarawak'. ${ }^{12}$ This spe-

is on that day domiciled in the Federation or in Singapore; or (b) is the issue of that person (see Art. 160(2) Federal Constitution).

7. Article $161 \mathrm{~A}(6)(\mathrm{b})$ of the Federal Constitution provides that a native in relation to Sabah is a person who is a citizen, is the child or grandchild of a person of a race indigenous to Sabah, and was born (whether on or after Malaysia Day [16 September 1963) or not) either in Sabah or to a father domiciled in Sabah at the time of birth.

8. Article $161 \mathrm{~A}(6)(\mathrm{a})$ of the Federal Constitution provides that a native in relation to Sarawak is a person who is a citizen, is the grandchild of a person of the Bukitan, Bisayah, Dusun, Sea Dayak, Land Dayak, Kadayan, Kalabit, Kayan, Kenyah (including Subup and Sipeng), Kajang (including Sekapan, Kejaman, Lahanan, Punan, Tanjong and Kanowit), Lugat, Lisum, Malay, Melano, Murut, Penan, Sian, Tagal, Tabun and Ubit race or is of mixed blood deriving exclusively from these races.

9. Orang Asli are defined as 'the Aborigines of the Malay Peninsula' and are officially classified into 18 sub-ethnic groups consisting of three broad groups, namely, the Negrito, Senoi and Aboriginal Malays (see Department of Orang Asli Development, The Orang Asli of Malaysia $<$ www.jakoa.gov.my/en/> (last visited 26 May 2017)).

10. SUHAKAM, Report of the National Inquiry into the Land Rights of Indigenous Peoples (2013), at 10-11.

11. This is the domestic equivalent of the 'King' in Malaysia who is appointed on a rotational basis every 5 years by and from the Council of Rulers of the States in Peninsular Malaysia that have monarchs as a head of state (see Federal Constitution, Arts. 33-38, Third and Fifth schs.).

12. This article was introduced when Sabah, Sarawak, the Federation of Malaya and Singapore formed Malaysia in 1963 
cial position includes reservations of positions in the public service, scholarships and other educational and training privileges and licences for the operation of any trade or business required by federal law. ${ }^{13}$ In terms of land, Article 161A(5) of the Federal Constitution permits any provision of state law for the 'reservation of land...or for alienation' to natives of Sabah and Sarawak or 'for giving them preferential treatment as regards the alienation of land by the State'.

In contrast, Peninsular Malaysia Orang Asli do not enjoy such overt constitutional rights as they are legally dependent on the federal government to exercise its discretion for their welfare, possibly due to their lack of political power when the Malayan and, subsequently, the Federal Constitution was forged in 1957 and 1963, respectively. Item 16 of the Ninth schedule of List I of the Federal Constitution specifically empowers the federal government to legislate for the welfare of Orang Asli. ${ }^{14}$ Article $8(5)(\mathrm{c})$ of the Federal Constitution permits laws 'for the protection, well-being or advancement' of Orang Asli 'including, the reservation of land' or the 'reservation to Orang Asli of a reasonable proportion of suitable positions in the public service' without offending the equal protection clause of the Federal Constitution contained in Article 8(1). Despite enabling positive discrimination laws in favour of Orang Asli, these constitutional provisions do not expressly oblige the federal government ${ }^{15}$ to safeguard the position of the Orang Asli. Natives of Sabah and Sarawak also enjoy broader constitutional protection against laws that touch upon their respective customs ${ }^{16}$ while Orang Asli have no equivalent protection with respect to their languages, laws, traditions, customs and institutions.

Despite these different levels of constitutional protection, both native and Orang Asli communities, similar to other indigenous peoples internationally, have shared a long history of dispossession of their customary territories, a predicament exacerbated by their lack of security of tenure over these areas. ${ }^{17}$ More recently, increased demand for lands and resources has resulted in acute

13. Article 153(2)

14. Article 74(1) of the Federal Constitution empowers the federal government to legislate for matters enumerated in the Federal list (Ninth sch. List I) and Concurrent List (Ninth sch. List III).

15. Notwithstanding, the Malaysian courts have held that the federal and state governments owe Orang Asli a fiduciary duty to protect the welfare of the Orang Asli, including their lands when Orang Asli have taken the Federal and State governments to court for third party encroachments over lands proven to be Orang Asli customary areas. The findings were supported by constitutional and statutory provisions and other sources (see Sagong bin Tasi v. Kerajaan Negeri Selangor (2002) 2 MLJ 591, at 618-19). For an overview on the scope of the fiduciary duty owed to the Orang Asli, see Y. Subramaniam, 'Affirmative Action and Legal Recognition of Customary Land Rights in Peninsular Malaysia: The Orang Asli Experience', 17(1) Australian Indigenous Law Review 103 (2013), at 109.

16. Federal Constitution, Arts. 76(2) and 150(6A). There are also constitutional rights for the resolution of such disputes by the Syariah courts (see Federal Constitution, Art. 121(1A)) in respect of Malays and native courts (see Federal Constitution, Art. 72(20) and Ninth sch, List IIA, Item 13) in respect of natives of Sabah and Sarawak.

17. For an acknowledgment of these issues by the Malaysian Human Rights Commission, see e.g. SUHAKAM (2013), above n. 10, at v-vi. encroachment and appropriation of the remaining areas inhabited by local indigenous communities. ${ }^{18}$ These problems exist for the natives of Sabah and Sarawak in spite of the express legal recognition of native customary rights (NCR) in both Sabah ${ }^{19}$ and Sarawak. ${ }^{20}$ Part of the problem lies with the fact that the relevant written laws in Sabah and Sarawak empower the respective state executives to determine the extent of legal recognition and protection granted in respect of native customary lands. ${ }^{21}$ More visibly in Peninsular Malaysia, the statutory power of the individual state government to recognise and protect Orang Asli land and resource rights through the grant of title, reservations, licenses and exemptions under written law has not worked to the advantage of the Orang Asli. 22

The indigenous land, territory and resource issue and the apparent failure to effectually crystallise the special constitutional and legal position of Malaysian indigenous peoples was examined in the 2013 Malaysian Human Rights Commission (SUHAKAM) Report of the National Inquiry into the Land Rights of Indigenous Peoples (the SUHAKAM Report), a culmination of an 18-month public inquiry into indigenous land rights issue commissioned by the Malaysian government. ${ }^{23}$ The SUHAKAM Report suggests that the definitional scope and implementation of laws enacted in favour of indigenous communities are the root legal causes for the indigenous land rights problem. Notwithstanding court pronouncements recognising indigenous customary rights, the SUHAKAM Report found that state legislatures and executives had, amongst other matters and in common, determined the scope of legal recognition afforded in respect of indigenous customary territories in a manner that reduced the spatial extent of indigenous territories and limited indigenous participation in respect of matters affecting their lands and resources. ${ }^{24}$ Compounding matters, existing laws and policies relating to lands and resources were not effectively implemented in favour of indigenous communities, with the respective governments deprioritising the rights of these communities in favour of other agendas. ${ }^{25}$

In terms of redress for the loss of customary territories, there are legal provisions for the payment of monetary compensation under statutory law when indigenous lands, territories and resources are expropriated or

18. Open Society Justice Initiative ('OSJI'), Strategic Litigation Impacts on Indigenous Peoples' Land Rights (2017), at 31-32.

19. See e.g. Sabah Land Ordinance, ss. 15, 65 and 66.

20. See e.g. Sarawak Land Code, s. 5.

21. For statutory scope of 'recognised' NCR as determined by the State, see e.g. nn. 19 and 20 above. In respect of State administrative powers to determine NCR claims in Sabah, see e.g. Sabah Land Ordinance, ss. 81 and 82. In respect of the State powers for the creation of Native Communal Reserves and the granting of permits for native claimants after 1958 In Sarawak, see e.g. Sarawak Land Code ss. 6 and ss. 5(1) and 10 respectively.

22. For statistics and observations on the State's poor performance in protecting Orang Asli lands, see SUHAKAM (2013), above n, 10, at 132.

23. See SUHAKAM (2013), above n. 10.

24. Id., at 101-4 (Sabah); 124-5 (Sarawak); 149-51 (Peninsular Malaysia).

25. Id., at 105-7 (Sabah); 126-7 (Sarawak); 151-2 (Peninsular Malaysia). 
rights to such areas are extinguished. ${ }^{26}$ However, the adequacy of the statutory compensation scheme is arguable since for most indigenous peoples it is not the monetary value of the land which is at stake, but rather access to their ancestral territories to maintain and perpetuate their own way of life. As such, the return of indigenous lands, territories and resources expropriated or taken is regarded as more vital to indigenous communities. In this respect, there are no statutory provisions that provide for the remedy of restitution or return of indigenous lands, territories and resources. Faced with the threat of being stripped of their remaining customary territories, affected indigenous communities have, in addition to other political responses, sought redress in the courts from the late 1980s for their dilemma and in particular employed the common law to some measure of success.

\section{The Malaysian Courts' Recognition of Indigenous Customary Rights}

Applying international common law developments on indigenous land rights, ${ }^{27}$ the Malaysian courts have, since 1996, recognised the pre-existing customary land rights of indigenous peoples without the need for formal recognition by the legislature or executive. ${ }^{28}$ In Adong bin Kumau E Ors v. Kerajaan Negeri fohor and Anor ('Adong $H C$ '), ${ }^{29}$ the High Court awarded the sum of RM26.5 million as compensation for the loss of JakunOrang Asli foraging lands expropriated for the construction of a dam on the basis of the privileged constitutional, statutory and common law status held by Peninsular Malaysia Orang Asli. Essentially, the Court recognised the principles of common law native title from other common law jurisdictions, including the landmark decisions of Mabo v. Queensland [No 2] $]^{30}$ ('Mabo [No 2]')

26. See e.g. Aboriginal Peoples Act 1954 ('APA'); ss. 11 and 12 (Peninsular Malaysia); Sarawak Forest Ordinance, ss. 4(1)(c), 11, 17, 24, 26(1)(c), 35(2)-(4), 39; Sarawak Land Code, ss. 5(3), (4) and (6); Sabah Forest Enactment, s. 13; Sabah Land Ordinance, ss. 16, 83; Sabah Land Acquisition Ordinance.

27. For commentary on these developments internationally, see P.G. McHugh, The Modern Jurisprudence of Tribal Land Rights (Oxford: Oxford University Press) (2011).

28. See e.g. Adong bin Kuwau v. Kerajaan Negeri Johor [1997] ('Adong $H C$ ') 1 MLJ 418 Kerajaan Negeri Johor v. Adong bin Kuwau ('Adong (A') [1998] 2 M.L.J 158, (Court of Appeal, Malaysia); Sagong bin Tasi v. Kerajaan Negeri Selangor ('Sagong $H C$ ') [2002] 2 MLJ 591; Sagong CA [2005] 6 MLJ 289; Nor Anak Nyawai v. Borneo Pulp Plantation Sdn Bhd ('Nor Nyawai HC') [2001] 6 MLJ 241; Superintendent of Lands \& Surveys, Bintulu v. Nor Anak Nyawai and another appeal ('Nor Nyawai CA') [2006] 1 MLJ 256 (Court of Appeal, Malaysia). For an analysis of the relevant jurisprudence, see SUHAKAM (2013), above n. 10, at 68-80; Y. Subramaniam, Orang Asli Land Rights by UNDRIP Standards in Peninsular Malaysia: An Evaluation and Possible Reform (PhD Thesis, University of New South Wales, 2012), chs. 6 and 7).

29. Adong HC [1997] $1 \mathrm{MLJ} 418$, at 426-33.

30. (1992) 175 C.L.R 1 and Calder v. $A G^{31}$ ('Calder') from Australia and Cana$\mathrm{da}$, respectively. In doing so it recognised the continued legal enforceability of pre-existing Orang Asli rights to their ancestral and customary lands held as native inhabitants. Adong $H C$, which was affirmed on appeal in $1998,{ }^{32}$ opened the door for indigenous communities to assert their customary territorial rights in the courts beyond codified law. To some extent, the common law recognition of pre-existing rights of indigenous peoples was subsequently found to be applicable to NCR in the jurisdictions of $\mathrm{Sabah}^{33}$ and Sarawak. ${ }^{34}$

The Malaysian superior courts' recognition of pre-existing rights of indigenous peoples to their ancestral and customary lands at common law has complemented existing protections afforded to Orang Asli and natives of Sabah and Sarawak under the Federal Constitution and written law. Due to the Malaysian legal system's common law roots from British rule, the doctrine of judicial precedent means that decisions of the superior courts - meaning the Federal Court and Court of Appeal - are usually binding upon the lower courts in subsequent similar cases. Under Articles 160(2) and 162 of the Federal Constitution, the common law as developed in Malaysia forms part of 'existing law' in Malaysia and is therefore legally binding. ${ }^{35}$

\subsection{Madeli bin Salleh and the Source of Common Law Rights}

In 2007, the apex court of Malaysia, namely the Federal Court, affirmed Adong $H C$ and the subsequent Sarawak decision of Nor Anak Nyamai's domestic application of Mabo [No 2] and Calder as a question of lam when ruling that the Malaysian common law recognises and protects the pre-existing rights of indigenous people in respect of their lands and resources. ${ }^{36}$ In doing so, a unanimous panel in Madeli bin Salleh held, amongst other matters, that the common law was not mere precedence but formed part of the substantive law in Malaysia and that the recognition of such indigenous rights was in accordance with the provisions of the Civil Law Act 1956, the relevant legislation enabling the domestic application of the common law. ${ }^{37}$

According to the Federal Court in Madeli bin Salleh, the source of the recognition of indigenous rights to lands and resources at common law in Malaysia lay in its application of the 'general statement of the common law' enunciated 'throughout the Commonwealth' in Mabo [No 2], Calder and other colonial decisions of the Privy Council that 'the courts will assume that the Crown intends that rights of property of the (native)

31. [1973] S.C.R. 313.

32. Adong CA [1998] 2 MLJ 158.

33. Rambilin binti Ambit v. Assistant Collector for Land Revenues Pitas (Judicial Review K 25-02-2002).

34. See e.g. Nor Nyawai HC [2001] 6 MLJ 241; Nor Nyawai CA [2006] 1 MLJ 256.

35. Superintendent of Land and Surveys Miri Division v. Madeli bin Salleh (suing as Administrator of the Estate of the Deceased, Salleh bin Kilong) ('Madeli ') [2008] 2 MLJ 677, at 690-1 (Federal Court).

36. See Madeli [2008] 2 MLJ 677, at 692.

37. See Madeli [2008] 2 MLJ 677, at 692. 
inhabitants are to be fully respected' and that '[t]he Crown's right or interest is subject to any native rights over such land'. ${ }^{38}$

Since then, the Malaysian courts have developed their own brand of common law domestic jurisprudence on the recognition of indigenous rights to lands, territories and resources guided by local laws and circumstances. In this regard, there are nonetheless several observations that can be made from Madeli bin Salleh that suggest a guarded and insular judicial approach to common law indigenous rights. First, the Federal Court, having recognised the legal continuity of indigenous rights to land at common law in its reasoning, went on to refer to prior executive edicts and orders expressly recognising such rights to reinforce its decision, ${ }^{39}$ when there was no legal necessity to do so. Further, the lower court decisions of Adong HC and Nor Nyamai recognising indigenous rights to land affirmed by the Federal Court were not solely based on the common law but were equally justified by the particular constitutional status ${ }^{40}$ held by the indigenous claimants. ${ }^{41}$ Finally, the Federal Court did not employ any sources of international law in arriving at its decision, possibly indicating a reluctance to apply international norms which will be revisited in Section 4.2.2.

\subsection{Relevant Characteristics of Common Law Doctrine in Malaysia}

The main characteristics of common law indigenous land and resource rights in Malaysia can be said to have been derived from early 'recognition' jurisprudence from Canada and Australia, ${ }^{42}$ qualified however by domestic constitutional and statutory provisions for the recognition, regulation and protection of such rights. Notwithstanding these legal provisions, it can be seen that the relevant features of the common law doctrine in Malaysia are not dissimilar to general common law principles in Australia and Canada. The Malaysian superior courts have held that the radical title held by the state is subject to any pre-existing rights held by indigenous people. ${ }^{43}$ These rights are primarily established by way of prior and continuous occupation of the claimed areas $^{44}$ and oral histories of the claimants relating to their customs, traditions and relationship with these areas. ${ }^{45}$ 'Occupation' of land does not require physical presence but evidence of continued exercise of control over the land. ${ }^{46}$

38. [2008] 2 MLJ 677, at 691-2

39. [2008] 2 MLJ 677, at 693-4.

40. For the relevant constitutional provisions, see $\mathrm{nn}$. 11-16 above and accompanying text.

41. Adong HC [1997] 1 MLJ 418, at 431-2; Nor Nyawai HC [2001] 6 MLJ 241 , at $277-8,297,298$

42. See n. 38 above and accompanying text. For observations on the extensive application of Canadian and Australian jurisprudence by the Malaysian courts in this regard and some comparative analysis, see Subramaniam (2012), above n. 28, at chs. 6 and 7

43. See e.g. Sagong CA [2005] 6 MLJ 289, at 301-2; Madeli [2008] 2 MLJ 677 , at 692.

44. See Nor Nyawai CA [2006] 1 MLJ 256, at 269.

45. See Sagong HC [2002] 2 MLJ 591, at 610, 621-4.

46. Madeli [2008] 2 MLJ 677, at 694-5.
These rights can be taken away through legal extinguishment by the state or alternatively, if the local indigenous community is demonstrated to have abandoned its lands, territories and resources. Legal extinguishment of these rights may be by way of plain and unambiguous words in legislation ${ }^{47}$ or an executive act authorised by such legislation. ${ }^{48}$ If these rights are extinguished, adequate compensation, meaning compensation that is just in the circumstances, is due in accordance with Article 13 of the Federal Constitution. ${ }^{49}$ Indigenous customary rights under Malaysian law are therefore susceptible to unilateral extinguishment by law, with relatively little jurisprudential development on the principle of free, prior and informed consent of indigenous communities in matters affecting their lands, territories and resources.

At present, the remedy of restitution in Malaysia appears to be limited to circumstances where the court determines that the extinguishment has been wrongful or there has been no extinguishment by plain and obvious words. ${ }^{50}$ The term 'wrongful' extinguishment here refers to circumstances where the state possesses the statutory power to extinguish NCR as in the cases of Sabah and Sarawak but may have exercised that power unlawfully. Practically, the argument that there has been no extinguishment of rights has been and is more likely to arise in the case of the Peninsular Malaysia Orang Asli as the written laws of Peninsular Malaysia do not recognise Orang Asli customs relating to lands and resources, let alone evince a 'plain and obvious' legislative intent to extinguish those rights.

\subsection{Restitution as a Remedy for Indigenous Dispossession?}

In terms of restitution, the Malaysian Court of Appeal has returned and alienated settled and cultivated customary lands and reserved foraging areas in favour of Semelai-Orang Asli claimants who had continuously occupied and inhabited those areas before the creation of a Malay reservation. ${ }^{51}$ In Sarawak, the Court of Appeal has ordered the return of leasehold lands to natives who had established prior customary rights. ${ }^{52}$

Although the judicial return of indigenous lands seems to be legally permissible in Malaysia, indigenous communities would have to overcome the barriers of establishing their claims by evidence and the doctrine of extinguishment before the remedies of restitution or adequate compensation are ordered by the court. Addition-

47. Ketua Pengarah Jabatan Hal Ehwal Ehwal Orang Asli \& Anor v. Mohamad bin Nohing (Batin Kampung Bukit Rok) \& Ors and another appeal ('Nohing CA') [2015] 6 MLJ 527, at 542-4; Madeli [2008] 2 MLJ 677, at $690,696-7$.

48. Madeli [2008] 2 MLJ 677, at 689, at 698

49. Adong CA [1998] 2 MLJ 158, at 163-4; Sagong HC [2002] 2 MLJ 591, at 617; affirmed, Sagong CA [2005] 6 MLJ 289, at 309-10; Madeli [2008] 2 MLJ 677, at 691-2.

50. Nohing CA [2015] 6 MLJ 527, at 542-4

51. Id.

52. See e.g. Superintendent of Lands and Surveys, Kota Samarahan Division v. Luking ak Uding ('Luking') [2016] 2 MLJ 783; Superintendent of Lands and Surveys Department Sibu Division v. Usang ak Labit [2014] 3 MLJ 519. 
ally, the issue of whether indefeasibility of grants of title trump prior indigenous customary rights across all three jurisdictions, meaning Sabah, Sarawak and Peninsular Malaysia, has yet to be authoritatively determined by the Malaysian courts. ${ }^{53}$ As will be observed in Sections 4 and 5 below, indigenous communities face legal and extra-legal problems in securing the restitution of their current lands, territories and resources, which transcend issues of proof and extinguishment of rights.

\section{Legal Challenges to Litigating Restitution of Indigenous Territories}

This section examines the obstacles faced by Malaysian indigenous communities in negotiating the litigation process to secure customary territorial rights before analysing the main vulnerabilities and limitations relating to the substantive common law jurisprudence on the recognition and restitution of indigenous customary areas. Observations are also made on the practical utility and resilience of court litigation as a mode for the return of indigenous territories to the community. The analysis will focus on both general issues confronting indigenous plaintiffs claiming recognition of common law customary rights and those seeking the remedy of restitution.

\subsection{The Litigation Process}

In the first place, many potential indigenous litigants in Malaysia cannot afford legal services and are not provided legal aid for customary land rights litigation, ${ }^{54}$ thus dashing the prospect of many a claim from its outset. If the community is able to secure legal representation, indigenous litigants constantly have to grapple with marshalling community participation, decision-making and unity throughout the litigation process, ranging from the gathering of evidence to support a claim to trusteeship matters relating to the fruits of litigation in the event of a successful claim. ${ }^{55}$ Disunity within the claimant community ${ }^{56}$ and breaches of trust in relation to compensation monies ${ }^{57}$ have functioned to prejudice and defeat claims and deprive successful litigants, respectively. Once a community finds the joint will to pursue litigation, their doors open to a long and arduous process that does not inevitably translate to an immediate remedy to their problem. To illustrate, the Temuan-

53. At the time of writing, the Federal Court is deliberating this issue in the context of Sarawak. This case is discussed in Section 4.2.3.

54. See OSJ (2017), above n. 18, at 6, 76; Y. Subramaniam, 'Orang Asli, Land Rights and the Court Process: A "Native Title" Lawyer's Perspective' in K. Endicott (ed.), Malaysia's Original People: Past, Present and Future of the Orang Asli (Singapore: National University Press) (2015), 423-45, 432-3.

55. For a practical examination of issues surrounding indigenous land rights litigation in Malaysia, Kenya and Paraguay, see generally, OSJ (2017), above n. 18.

56. See OSJI (2017), above n. 18, at 58.

57. Id., at 35 (n. 87).
Orang Asli claimants in the Sagong bin Tasi case ${ }^{58}$ endured 12 years of litigation including appeals before they were adequately compensated for the loss of their customary lands acquired for the construction of a highway. And in the Semelai-Orang Asli case of Mohamad bin Nohing, ${ }^{59}$ despite all avenues for appeal being exhausted in March 2016, the Court of Appeal's 2015 decision to return and alienate the Semelai-Orang Asli's land has yet to see fruition due to various administrative delays. ${ }^{60}$

As seen in other jurisdictions, ${ }^{61}$ the formal setting and adversarial nature of civil proceedings are arguably at odds with indigenous perspectives on dispute resolution, which are relatively less formal and more participatory. This can make giving evidence for indigenous witnesses an extraordinarily difficult ordeal, and perhaps more importantly, put them at a tactical disadvantage compared to other witnesses. ${ }^{62}$ Language barriers, particularly in the case of community elders who may not have a sufficiently good command of the official language of the Malaysian courts (Malay or English), can function to weaken the plaintiffs' claim. Epistemological differences between indigenous worldviews and those of others also do not necessarily work to the advantage of an indigenous witness in court.

Aggravating matters for indigenous claimants, the Malaysian courts have prescribed an overly circumspect view that testimonies by 'self-serving' indigenous plaintiffs in support of their claims 'should carry little or no weight in the absence of some other credible corroborative evidence'. ${ }^{63}$ Indigenous laws, customs and traditions in Malaysia are steeped in oral histories and would be at a handicap compared to the written word of others, particularly official maps and documents, which ironically and in many ways, are 'self-serving' in their own right.

The evidential burden in civil claims has functioned to defeat indigenous land rights claims in other commonwealth jurisdictions. ${ }^{64}$ While the Malaysian courts have been said to have adopted a relatively more relaxed and sensitive judicial approach towards the proof of customary rights, ${ }^{65}$ the need for supporting evidence, particularly in light of the relative dearth of documentation directly relating to historical indigenous occupation, use and enjoyment of areas claimed, remains a challenge in Malaysia. This requirement necessitates corroborative expert evidence, documents and maps to assist in the

58. See Sagong HC [2002] 2 MLJ 591; Sagong CA [2005] 6 MLJ 289

59. Nohing CA [2015] 6 MLJ 527 (Court of Appeal).

60. Interview with Ms Tan Hooi Ping from Messrs Lee Hishamuddin Allen Gledhill, solicitors for the Semelai-Orang Asli plaintiffs, 27 April 2017.

61. For example, in respect of Canada, see e.g. Royal Commission on Aboriginal Peoples, Report of the Royal Commission on Aboriginal Peoples (1996), at vol 2, Part 2, ch 4 s 1, <https://www.bac-lac.gc.ca/eng/ discover/aboriginal-heritage/royal-commission-aboriginal-peoples/ Pages/final-report.aspx>, 6 December 2017 and Australia, see e.g. Sean Brennan et al, Treaty (2005), at 114-16

62. See Subramaniam (2015), above n. 54, at 439

63. Nor Nyawai CA [2006] 1 MLJ 256, at 272.

64. For a broad discussion of these issues, see e.g. McHugh (2011), above n. 27, at 258-68.

65. McHugh (2011), above n. 27, at 193 
court's deliberation. Furthermore, the controversial nature of indigenous claims, which involve the state and large corporations, may function to reduce the number of experts willing to testify on behalf of indigenous claimants. Perhaps more pertinently, the lack of financial resources to fund the court case and to engage an expert, work to the detriment of indigenous litigants.

However, there is also precedent from the Malaysian Court of Appeal that propounds a 'realistic approach' when considering supporting evidence in customary rights claims, taking cognisance of the claimants' reliance on oral evidence and the impediments in producing surveyed maps and official documentation. ${ }^{66}$ In advocating this approach, the Court seems to have taken cues from the Canadian Supreme Court in Delgamuukm v. British Columbia, ${ }^{67}$ which acknowledges the evidential difficulties inherent in aboriginal land claims and the need to have regard to aboriginal perspectives in such matters. If there are lessons to be learnt from Canada, it is that much remains to be done to address the larger issues of structural bias and cultural difference and control that indigenous peoples encounter in bringing their cases to the Canadian courts in spite of the courts' acknowledgment of interpretative difficulties and consideration of aboriginal perspectives. ${ }^{68}$

In any event, the contrasting approaches taken by the Malaysian court in considering evidentiary matters in an indigenous land and resource rights claim epitomises the uncertainties inherent in the litigation process which, as will be observed in the following section, transcends procedural law and moves into the substantive jurisprudence on indigenous rights and remedies relating to their customary lands, territories and resources.

\subsection{The Evolving Jurisprudence}

The spatial extent of indigenous areas legally recognised by the Malaysian courts through the common law jurisprudence, the Malaysian courts' application of international norms, and the resilience of common law recognition of rights when pitted against overlapping land and resource interests created by the state are vital aspects in evaluating the overall effectiveness of the courts in the restitution of indigenous lands, territories and resources. All these aspects of the doctrine are examined in the following sections.

\subsubsection{The Recognition of Unsettled and Uncleared Areas}

Following established jurisprudence including the landmark Privy Council opinion in Amodu Tijani v. The Secretary, Southern Nigeria, where property rights peculiar to native communities throughout the British commonwealth were legally recognised through the common law, ${ }^{69}$ the Malaysian Court of Appeal observed that the precise nature of indigenous customary rights to lands

66. Abu Bakar bin Pangis v. Tung Cheong Sawmill Sdn Bhd [2014] 5 MLJ 384, at 407-8.

67. [1997] 3 SCR 1010, at 1065-1066.

68. See e.g. J. Borrows, 'Listening for Change: The Courts and Oral Tradition', 39(1) Osgoode Hall Law Journal 1 (2001).

69. [1921] 2 A.C. 399. and resources is 'determined by the customs, practices and usages of each individual community' and this matter 'is a question of fact' to be determined by the court. ${ }^{70}$ In other words, common law indigenous customary land rights in Malaysia do not 'owe their existence to any statute' or executive declaration. ${ }^{71}$ It would therefore follow that these rights exist independently of written law, a proposition supported by the decision in Adong $H C$ where the court held 'in order to determine the extent of aboriginal peoples' full rights under law, their rights under common law and statute has to be looked at conjunctively, for both these rights are complementary...' ${ }^{72}$

Accordingly, the Malaysian courts have granted rights ranging from usufructuary rights $(53,000$ acres of foraging land in Adong $H C$ ) to customary title (38.77 acres of settled lands in Sagong $\mathrm{HC}^{73}$ ) in favour of indigenous claimants who have been able to establish customary rights through prior and continuous occupation of and/or the maintenance of a traditional connection with the land in accordance with distinctive customs of the claimant group. However, most defendants have consistently disputed the legal right of indigenous communities to unsettled lands, which would include hunting and foraging areas. Specifically, the Sarawak state government has disputed whether the common law recognition of NCR should extend beyond cleared and settled areas as the written laws of Sarawak do not expressly provide for the recognition of traditional forest areas set aside by native communities for, amongst others, hunting and the collection of forest produce.

Despite earlier jurisprudence that such native customs need not be contained in written laws to be recognised under the common law, this issue found its way to the Federal Court in Director Of Forest, Saramak v. TR Sandah Tabau ('TR Sandah FC') ${ }^{74}$ in 2015 where the Federal Court had to determine whether the common law recognition of NCR or, more specifically, Iban customary rights, extended to the broader native customary territory ('pemakai menoa') and forest reserved for food and forest produce ('pulau'), primarily because these customs were never contained in any of the legislation and executive orders relating to Sarawak. ${ }^{75}$

In December 2016, the Federal Court found in favour of the state and other appellants and allowed their appeals by a majority decision of $3: 1$ but of greater consequence were the findings of the court on the legal questions posed on the scope of the recognition afforded to the Iban natives by the common law in the state of Sarawak.

Of the five judges on the panel (of which one judge had retired before the Federal Court judgment was handed

70. Sagong CA [2005] 6 MLJ 289, at 301-2.

71. Sagong HC [2002] 2 M.L.J 591, 612; Nor Nyawai CA [2006] 1 MLJ 256 , at 270.

72. Adong HC [1997] 1 MLJ 418, at 431 .

73. [2002] 2 MLJ 591.

74. [2017] 3 CLJ 1.

75. See TR Sandah FC [2017] 3 CLJ 1, at 16-17 for the questions of law posed to the Federal Court. 
down), Raus PCA (with Ahmad Maarop FCJ concurring) held that the pre-existence of rights under native laws and custom, which the common law respected, were limited to the Iban custom of temuda (covering cleared, settled and cultivated lands) and did not encompass rights to land in the entire customary territory and the primary forest which natives had not felled or cultivated (meaning the Iban customs pemakai menoa and pulau, respectively) because these rights had not been recognised by the laws of Sarawak. ${ }^{76}$

In arriving at this finding, Raus PCA confined himself to construing the written laws, edicts and executive orders of Sarawak because in his Honour's view, that 'customs which the laws of Sarawak recognise' were limited to written laws that had been given the force of law ${ }^{77}$ by the legislature and executive and not those recognised through the common law by the courts. Perhaps focusing more on the specific legal history of Sarawak, Raus PCA had earlier cited with approval the Peninsular Malaysia decisions of Adong HC and Sagong, ${ }^{78}$ which had recognised Peninsular Malaysia indigenous customary rights at common law, including rights to foraging areas notwithstanding that there had been no prior legislative or executive sanction for such rights. ${ }^{79}$

In dissent, Zainun Ali FCJ held that the fact that neither the pemakai menoa nor pulau were not contained in the written law of Sarawak would preclude the recognition of those rights under the common law. Her Ladyship observed in the following terms:

...the repeated reliance on the fact that these customs have never received legislative recognition misses the heart of the appeal in this case.

[214] With respect, the submission of the appellant thus far, does not seem to add up. In other words, the wrong weight has been given to legislation - it should not and has never been completely determinative/ fatal to recognition in the common law. The two are separate questions. And that the lack of regulation does not mean that there is no existence - there is no logical link between the two, merely a descriptive one (what we could, perhaps call a correlation). Customs are sui generis and do not find their roots in statute, hence they are called customs. ${ }^{80}$

Having effectively answered the legal questions posed favouring the natives in holding that the common law recognition of NCR was 'a question of evidence' rather than law, ${ }^{81}$ the fourth judge, Abu Samah FCJ, remarkably found it unnecessary to answer the questions posed to the court on the basis of his opinion that the plaintiff

76. TR Sandah FC [2017] 3 CL 1 , at 36.

77. Id., at 33.

78. Id., at $22-26$

79. Id., at 29-30. For general principles on the common law doctrine in Malaysia, see above nn. 27-50 and accompanying text.

80. Id. at 63

81. Id. at $84-85$ had failed to prove their claims on a balance of probabilities. $^{82}$

The majority decision in TR Sandah $F C$ is pending review, a process that is successful only in the most exceptional of circumstances. Currently, it is also unclear as to the extent to which the Malaysian courts will apply the majority decision in the jurisdictions of Peninsular Malaysia and Sabah given the questions posed and the determination made in respect of particular legal circumstances in Sarawak. Merits aside, the decision in TR Sandah FC in effect limits the remedy of restitution in the state of Sarawak by confining enforceable indigenous customary rights to cleared, settled and cultivated areas.

The lack of doctrinal reasoning by the majority of the Federal Court as to why the continuity of pre-existing customary rights without the need for formal recognition, as recognised by established common law principles and affirmed by the Federal Court in Madeli bin Salleh, should only be limited to cleared, settled and cultivated areas and not larger hunting and foraging areas begs the question of a possible predisposition towards sedentism of indigenous communities. Sedentism and eventual integration of indigenous communities, as contained in the ILO Convention $107,{ }^{83}$ the earliest international treaty explicitly recognising indigenous rights, has since been considered to be outmoded and no longer reflective of international human rights standards on indigenous self-determination. ${ }^{84}$ Such perspectives, if indeed dominant in the Malaysian courts, do not augur well both for the municipal judiciary and the domestic indigenous rights movement.

More generally, TR Sandah FC yet again illustrates the proposition that the development of indigenous rights through the courts is subject to regress and a degree of judicial unpredictability. ${ }^{85}$

\subsubsection{Reluctance to Apply International Indigenous Norms}

Despite there being instances where the Malaysian courts have utilised the provisions of international human rights conventions to which Malaysia is party in their deliberations, ${ }^{86}$ the appellate courts have demonstrated a marked reluctance to treat such provisions as legally binding or in 'sticking very closely's7 to those

82. Id. at 85-87

83. Convention Concerning the Protection and Integration of Indigenous and Other Tribal and Semi-Tribal Populations in Independent Countries, 26 June 1957, ILO C 107

84. See e.g. Xanthaki (2007), above n. 3, at 52-56, 67-71

85. This is not an altogether unfamiliar phenomenon. For the judicial curtailment of native title in Australia, see e.g. S. Brennan, 'Native Title in the High Court of Australia a Decade after Mabo', 14 Public Law Review 209 (2003)

86. See e.g. Noorfadilla Ahmad Saikin v. Chayed Basirun [2012] 1 CLJCLJ 769 in respect of the United Nations Convention on the Elimination of All Forms of Discrimination Against Women, 18 December 1979, 1249 UNTS 13; PP v. MFK [2010] 6 CLJ 95 in respect of the United Nations Convention on the Rights of the Child, 20 November 1989, 1577 UNTS 3.

87. Pathmanathan Krishnan v. Indira Gandhi Mutho [2016] 1 CLJ 911, at 935-7 (Court of Appeal). 
provisions unless they have been enacted into local laws. ${ }^{88}$ Malaysia is also not a party to any binding international conventions that directly concern indigenous rights to lands, territories and resources. As for the UNDRIP, which is a declaration rather than a binding treaty, the draft was referred to by the Court in Nor Anak Nyamai but the judge was quick to add that the document played 'no part in my decisions on the issues in this case since they do not form the law of our land' ${ }^{89}$ In the Federal Court appeal in Bato Bagi v. Kerajaan Negeri Saramak, Raus PCA observed in no uncertain terms:

[o]n the issue whether this court should use "international norms" embodied in the UNDRIP to interpret arts. 5 and 13 of the Federal Constitution I have only this to say. International treaties do not form part of our law, unless those provisions have been incorporated into our law. We should not use international norms as a guide to interpret our Federal Constitution. ${ }^{90}$

Perhaps more ambivalently, Zaki CJ observed on the invocation of the UNDRIP, 'it must still be read in the context of our Constitution', ${ }^{91}$ suggesting that the issue may be open for future consideration before less conservative appellate panels.

It can therefore be gleaned from this section that the judicial development of indigenous rights and remedies in Malaysia has been a slow and measured process, impaired by not only the vagaries of the legal process but periods where judicial conservatism is more pronounced.

\subsubsection{Extinguishment by Alienation?}

In Malaysia, extinguishment of indigenous customary land and resource rights at common law can take place by plain and unambiguous legislative words ${ }^{92}$ or in the case of Sabah and Sarawak, where there are express statutory provisions for the extinguishment of NCR. ${ }^{93}$ In either case, adequate compensation is payable to customary rights holders with no apparent right of restitution of appropriated lands and resources in the future. It is also clear that a mere reservation of land by the state without plain and clear legislative intent for extinguishment does not extinguish indigenous rights as such power 'cannot be derived by mere implication'. ${ }^{94}$

However, the Malaysian superior courts have yet to authoritatively determine whether the alienation of state lands to public or private owners amounts to an acquisition or extinguishment of indigenous customary rights to their lands, territories and resources. In this sense,

88. See e.g. Airasia Bhd v. Rafizah Shima Mohamed Aris [2015] 2 CLJ 510, at 521 (Court of Appeal).

89. [2001] 6 MLJ 241, at 297-8.

90. [2011] 6 MLJ 297, at 338.

91. Id. at 307

92. See above nn. 47-48 and accompanying text.

93. See e.g. s. 5(3), (4) and (6) Sarawak Land Code; s. 12(6) Sabah Forest Enactment.

94. Madeli [2008] 2 MLJ 677, at 696-7. common law jurisprudence may function as a doubleedged sword in Malaysia where indigenous rights can, in certain circumstances, be extinguished by a grant of title inconsistent with the continued enjoyment of such rights. $^{95}$

In Kong Chee Wai, the court nullified a document of title that overlapped with lands continuously occupied by the Semai Orang Asli plaintiffs and ordered the reservation of these and other lands where customary rights had been established. ${ }^{96}$ The Malaysian courts have also ordered the restitution of state-created leasehold interests to native claimants where NCR had been established as 'the issue of indefeasibility of title is dependent on the finding of fact whether the plaintiff had proved their NCR claim'. ${ }^{97}$ The legal justification for restitution seems to lie in the principle that the radical title held by the state is subject to any pre-existing rights held by indigenous people. ${ }^{98}$

That said, the Malaysian superior courts are due to revisit the remedy of restitution of indigenous lands and territories where lands continuously inhabited by indigenous claimants have been afterward alienated and registered in favour of subsequent owners. At the time of writing, the Federal Court is deliberating an appeal from Sarawak on the questions of: (i) whether indefeasibility of title under Land Code (Sarawak) remains applicable even if it can be shown that prior NCR had been created over land under the same Land Code; and (ii) if the proper remedy for the loss or infringement of NCR as a result of alienation where such rights exist without extinguishment should be an award of damages and not a declaration to nullify the title. ${ }^{99}$ In Peninsular Malaysia, the High Court, having held that the Seletar-Orang Asli plaintiffs had established customary rights to the lands in question, refused the plaintiffs' claim for return of lands that overlapped with alienated lands under the Peninsular Malaysia Land Code 1965 and instead ordered, the payment of adequate monetary compensation. ${ }^{100} \mathrm{~A}$ paramount consideration in refusing restitution was that the registered landowner defendants were innocent bona fide purchasers who also possessed constitutional and statutory rights to property that co-existed with but could not be overridden by prior indigenous customary rights. ${ }^{101}$ Both the plaintiffs and defendants have appealed against the decision.

In other jurisdictions, similar rulings have been viewed as discriminatory since it assumes that indigenous title is

95. See Mabo [No 2] (1992) 175 CLR 1, at 68

96. Kong Chee Wai v. Pengarah Tanah Dan Galian Perak [2016] 1 CLJ 605. In 2016, both State government and landowner appeals were dismissed by the Court of Appeal in Civil Appeal No. A-01-(NCVC) (A)-388-12/2015. As there was no leave to appeal to the Federal Court was sought against the decision, the Court of Appeal exercised its discretion not to provide formal written grounds for its decision.

97. Luking [2016] 2 MLJ 283, at 808 (Court of Appeal).

98. Id. See also above n. 43 and accompanying text.

99. TH Pelita Sadong Sdn Bhd v. TR Nyutan Ak Jami and other appeals (Federal Court Civil Appeal No: 01-26-12/2014 (Q)).

100. See Eddy Salim v. Iskandar Regional Development Authority (Johor Bahru High Court C.S. No. 22NCVC-158-06-2013), Grounds of Judgment, 18 June 2017.

101. Id. At 88 
'inferior and subordinate'. ${ }^{102}$ It will be interesting to observe how the Malaysian appellate courts deal with the issue of competing indigenous, state and private interests over land, particularly in light of the special constitutional position held by indigenous groups.

An unfavourable result for the indigenous communities could mean that the state could circumvent the remedy of restitution of indigenous lands by an administrative act of alienation, reducing legal recourse to a matter of monetary compensation. The issue of 'extinguishment by alienation' and other questions posed on the judicial return of indigenous lands, territories and resources, which possibly favours government interests, necessitates this article to move out of the courtroom and examine the political realities in securing the right to such restitution in Malaysia.

\section{Restitution of Indigenous Land and Territories in Malaysia: A Reality Check}

The relative inaction of the federal and state executive and legislature to give effect to the full gamut of indigenous customary land and resource rights recognised by the Malaysian courts coupled with persistent government appeals to reduce the scope of these rights indicates a lack of political impetus to do so. In Peninsular Malaysia, this issue has been attributed to a combination of: (i) historical and cultural prejudices against the numerically weaker Orang Asli; (ii) hierarchical, differentiated and contested definitions of indigeneity between the politically and numerically dominant ethnic Malays and the Orang Asli; (iii) Malaysia's subsequent push for economic progress, which is linked to ethnic Malay-centric affirmative action; and (iv) land and resource administration challenges linked to the deprioritisation of Orang Asli interests. ${ }^{103}$

Although the issue of native 'indigeneity' may not be as fundamental in Sabah and Sarawak, native political and numerical dominance at the provincial level in Sabah and Sarawak has not spared indigenous communities from government policy priorities and administrative problems, which have not given primacy to the effectual recognition of NCR to lands and resources. ${ }^{104}$

In this section, it will be contended that the want of political will to effectively recognise indigenous customary lands and resources in Malaysia is exacerbated in the

102. See e.g. Gilbert (2016), above n. 3, at 83-104

103. Subramaniam (2013), above n. 15, at 111-17

104. For a discussion of some of these issues, see SUHAKAM (2013), above n. 10 , at chs. 6 and 7 respectively. For recent commentary in relation to Sarawak, see e.g. J. Chin, 'The politics of native titles in Sarawak' new mandala, <www.newmandala.org/politics-native-titles-sarawak/> (last visited 11 March 2017). In relation to Sabah, see e.g. M.J. Munang, 'Land grabs in Sabah, Malaysia: Customary Rights as Legal Entitlement for Indigenous Peoples - Real or Illusory?' in C. Carter and A. Harding (eds.), Land Grabs in Asia; What Role for the Law? (London: Routledge) (2015), 137 case of the return of indigenous lands and resources, which in turn potentially plays an adverse role in the judicial recognition and restoration of these areas to indigenous claimants.

\subsection{A Case of Political and Economic Expediency?}

Fundamentally, restitution concerns the reparation of wrongs, whether past, continuous or present, committed by a person or a group against another. In international law, restitution is 'aimed at the reparation of the effects of a proceeding that was unlawful'. ${ }^{105}$ Consequently, a legally enforceable right to restitution of indigenous lands and resources would involve a judicial finding or, alternatively, an acknowledgment of a wrong by the perpetrator. Despite past observations made by the Malaysian judiciary on the governments' breach of fiduciary duty for failing to legally protect Orang Asli lands, ${ }^{106}$ the federal and state executives or legislature have yet to publicly accept, or for that matter apologise for, any wrongdoing committed in relation to indigenous land and resource policies and management. The Malaysian government's responses on indigenous land rights during Malaysia's last United Nations Universal Periodic Review (UPR) in 2013 best illustrate the position taken by the government in dealing with this issue. Some of the more pertinent responses from the Malaysian delegation from the UPR Working Group Report are reproduced here:

130. The delegation responded to questions and comments raised in the preceding interactive dialogue by reiterating that Orang Asli rights to land, beliefs, culture and non-discrimination were clearly provided for by the Federal Constitution and the Aboriginal People's Act 1954.

131. The Government clarified that a task force... had been established to review and formulate the necessary strategy regarding the issue of indigenous peoples' land rights, pursuant to the national inquiry into the land rights of indigenous peoples in Malaysia undertaken by SUHAKAM.

132. The Government continued to hold consultations with State authorities, other relevant agencies and indigenous groups on land issues. Progress had also been made in the survey and gazetting exercise for Orang Asli land.

133. Currently, the Government... was collaborating on a study... for the formulation of an Orang Asli national development plan.

134. Sarawak State, with a large indigenous population comprising 27 ethnic groups, ...had laws which recognized and protected indigenous rights to land... A survey to demarcate boundaries and guarantee

105. I. Vasarhelyi, Restitution in International Law (Budapest: Publishing House of the Hungarian Academy of Sciences) (1964), at 10.

106. See e.g. Sagong CA [2005] 6 MLJ 289, at 314; Pengarah Tanah dan Galian Johor v. Khalip bin Bachik [2013] 1 MLJ 799, at 812-13; Eddy Salim v. Iskandar Regional Development Authority (Johor Bahru High Court C.S. No. 22 NCVC-158-06-2013). 
security of tenure of NCR land was ongoing under the Government Transformation Programme.

135. The current development agenda...necessitated the use of NCR land. Where rights to NCR land were affected, the State ... (a) adopted best international practices...; and (b) provided affected indigenous communities with a comprehensive compensation package...

...137. In recognizing the challenges facing indigenous communities in Malaysia, the Government maintained that those communities must be afforded choice and be free to decide whether they wished to join mainstream society or not. ${ }^{107}$

Despite recognising indigenous land and resource rights to an extent and reporting initiatives to legally protect rights, the government did not acknowledge any accountability for its undue delay in settling the longstanding issue of indigenous land and resource rights. Paragraph 135 of the Report is equally revealing as it states that the current development agenda 'necessitated the use of NCR' land. Therefore, restitution of indigenous lands and resources from the current Malaysian government's perspective can be said not to be a question of reparation of wrongs but more of a question of political and economic expediency.

The national development narrative, with local idiosyncrasies, has justified, and in certain cases legitimized, the taking of indigenous traditional lands and territories in many emerging economies. ${ }^{108}$ Likewise in Malaysia, land use policies have been more oriented to land development for commercial agricultural production, or the extraction of revenue from the forests rather than environmental or forest protection, and continue to provide revenue for private enterprises and the state. ${ }^{109}$ As such, limiting the legal recognition, and more so the restitution of indigenous lands and resources in Malaysia, increases state revenue, which can be derived from such assets and enables such lands and resources to be exploited for amongst other purposes, commercial use. Due to vested state and commercial interests and the lack of political will to change the status quo, it remains to be seen how any proposed policy initiative for the return of lands and resources to indigenous minorities would play out politically. It should be appreciated that resource exploitation, cash crop cultivation and land development have been key factors in Malaysia's relatively successful economic story. In this setting, the recognition and potential return of close to $6 \%$ of Peninsular Malaysia's land mass of Orang Asli inhabited and used lands to the Orang Asli may not be compatible with broader

107. Human Rights Council, Report of the Working Group on the Universal Periodic Review Malaysia, HRC Doc. 25/10, 4 December 2013.

108. For such paradigms in South East Asia, see e.g. A. Xanthaki, 'Land Rights of Indigenous Peoples in Southeast Asia', 4(2) Melbourne Journal of International Law 467 (2003); More generally for land grabbing in this regard, see e.g. C. Carter and A. Harding (eds.), Land Grabs in Asia; What Role for the Law? (London: Routledge) (2015).

109. K.S. Jomo, Chang Y.T. and Khoo K.J., Deforesting Malaysia: The Political Economy and Social Ecology of Agricultural Expansion and Commercial Logging (London: Zed Books) (2004), at 140, 224-5. federal and state government land and resource use priorities.

Despite some public sympathy in Malaysia towards the plight of indigenous peoples and their lands and resources, the notion of negotiating and returning large tracts of valuable lands and resources to indigenous minorities in an environment where nationwide sentiments towards the reparation of historical injustices towards these minorities still appear to be questionable is a political risk that may not entice the voting populace. Accordingly, it is not startling that the concept of returning land and resources in favour of indigenous minorities has yet to find favour with the Malaysian politicians and lawmakers.

\subsection{Restitution and Indigenous Autonomy}

Restitution, including the restitution of lands and resources, is equally vital in establishing the foundation for long-term and lasting self-determination strategies for indigenous nations. ${ }^{110}$ In an international indigenous rights context, the right to self-determination has evolved from a concept understood as meaning statehood in the immediate post-colonial era to a right connected with decisions regarding the use, management and control of indigenous lands and resources. ${ }^{111}$

In this regard, Article 4 of the UNDRIP states 'Indigenous peoples, in exercising their right to self-determination, have the right to autonomy or self-government in matters relating to their internal and local affairs...' while Article 5 provides, amongst others, for the right of indigenous peoples to maintain and strengthen their distinct political, legal, economic, social and cultural institutions.

As fiduciaries for the natives and Orang Asli, ${ }^{112}$ the federal and state governments possess extensive legal powers for the protection of indigenous peoples and their lands. ${ }^{113}$ For instance, these powers include the statutory power to determine community headmen, ${ }^{114}$ which arguably goes against the indigenous self-determination of their decision-making institutions. Restitution of communal indigenous lands and resources through the courts would shift the balance of economic and political power from the state to local indigenous communities, a scenario that necessitates the state's release of the stranglehold it currently possesses over indigenous leadership and stewardship. Given the relative ease with which the state machinery and politicians in power can exert legal control over indigenous peoples and lands to fulfil their own endeavours, it would be hard to envisage

110. J. Corntassel and C. Holder, 'Who's Sorry Now? Government Apologies, Truth Commissions, and Indigenous Self-Determination in Australia, Canada, Guatemala, and Peru', 9(4) Human Rights Review 465 (2008), at 471.

111. For commentary on the nexus between indigenous self-determination and their lands, territories and resources, see e.g. Gilbert (2016), above n. 3, at 215-45

112. See Bato Bagi v. Kerajaan Negeri Sarawak [2011] 6 MLJ 297, at 326.

113. For constitutional powers, see above nn. 11-16 and accompanying text.

114. See e.g. APA, s.16 (Orang Asli); Sarawak Community Chiefs and Headmen Ordinance 2004, s. 5(1); (Sarawak); Native Courts Enactment, 1992, s. 2 (definition of 'headman') (Sabah) 
governmental support for the empowerment of indigenous peoples through the restitution of their lands and resources at present.

\subsection{Broader Perspectives on the Judicial}

Development of the Remedy of Restitution

Similar to other democracies, Malaysia is no exception to the principle of an independent and impartial judiciary and the broad principle of separation of powers amongst the legislative, executive and judicial arms of government. In the context of Malaysia, the judiciary has, however, not been short of its fair share of controversies surrounding allegations of executive and legislative interference. ${ }^{115}$

In 1988, Article 121 of the Federal Constitution, which vested judicial power in the High Court of Malaya and Borneo, was amended to state that the judicial powers of the Malaysian courts are no longer derived from the Constitution but are essentially limited to those conferred by the federal legislature. In the words of the Federal Court, 'if we want to know what are the specific jurisdiction and powers of the two High Courts, we will have to look at the federal law'116 and that the Federal Constitution 'does have the features of the separation of powers and at the same time, it contains features which do not strictly comply with the doctrine'. ${ }^{117}$

While concerns about the independence of the Malaysian judiciary may be seen as speculative particularly given its relatively progressive approach to indigenous land and resource rights, there is every possibility that judicial conservatism and 'strict legalism and literalism', still said to be prevalent in Malaysia in respect of other constitutional fundamental liberties, ${ }^{118}$ may function to curb the recognition and restitution of indigenous rights to lands and resources. This concern is not unfounded. In Nor Nyamai CA, the Court of Appeal made the following observation:

we are inclined to agree...that the claim should not be extended to areas where 'they used to roam to forage for their livelihood in accordance with their tradition'. Such view is logical as otherwise it may mean that vast areas of land could be under native custom-

115. For more recent work on the independence of the Malaysian judiciary, see e.g. P.J. Yap, Constitutional Dialogue in Common Law Asia (Oxford: Oxford University Press) (2015), at 66-73; H.P. Lee, 'Constitutional Developments in Malaysia in the First Decade of the Twenty-First Century: A Nation at the Crossroads', in A.H.Y. Chen (ed.), Constitutionalism in Asia in the Early Twenty-First Century (Cambridge: Cambridge University Press) (2014) 244, at 260; 269; Compare with A. Harding, The Constitution of Malaysia: A Contextual Analysis (Oxford: Hart Publishing) (2012), at 195-224.

116. PP v. Kok Wah Kuan [2008] 1 MLJ 1, at 14. But see dissenting judgment of Malanjum CJSS, at 20-26.

117. PP v. Kok Wah Kuan [2008] 1 MLJ 1, at 16

118. See e.g. F.S. Shuaib, 'Fundamental Liberties under the Federal Constitution: A Critical Analysis' in A.G. Hamid @ Khin Maung Sein (ed.), Human Rights Law: International, Malaysian and Islamic Perspectives (Petaling Jaya: Thomson Reuters) (2012) 293, at 309; B.T. Khoo, 'Between Law and Politics: the Malaysian Judiciary Since Independence' in K. Jayasuriya (ed.), Law, Capitalism and Power in Asia: The Rule of Law and Legal Institutions (London and New York: Routledge) (1999) 205. ary rights simply through assertions by some natives that they and their ancestors had roamed or foraged the areas in search for food. ${ }^{119}$

This arbitrary observation to limit NCR in Sarawak based on the concern that 'vast areas of land could be' subject to such rights has drawn judicial criticism for having 'no conceptual basis' and appearing to be 'judicial policy-making' ${ }^{120}$ Yet, this very statement provided the avenue for litigious dispute on the issue, which culminated in the Federal Court limiting NCR to settled and cultivated areas in Sarawak more than a decade later. ${ }^{121}$

The judicial remedy of restitution of indigenous lands and resources arguably runs counter to prevailing federal and state land and resource utilisation policies and the broader national development agenda. In Australia and Canada, court judgments on indigenous land rights have been critiqued for being influenced by extra-legal and political considerations. ${ }^{122}$ Will the Malaysian judiciary curtail the practicability of restitution and so effectually moderate legal redress to an outcome more consonant with the government programme? Will it resort to the 'safer' remedy of monetary compensation in lieu of restitution for loss of indigenous lands and resources? Past experience suggests that indigenous communities should not be overly optimistic for a favourable outcome.

\section{Conclusion}

In this article, it has been contended that the utilisation of the Malaysian courts for the restitution of indigenous lands and resources can be a potentially slow, costly, incongruous and unpredictable process. It is still unclear if the Malaysian courts will apply the law decisively to return indigenous lands and resources beyond that conferred upon by the executive and legislative arms of government. Court outcomes aside, indigenous land rights litigation in Malaysia has nonetheless been said to improve indigenous community and judicial awareness, participation and empowerment, increase public and media interest and have positive social and economic effects on indigenous communities. ${ }^{123}$ In this sense, the common law, as described by McHugh, is 'not an end in itself'. ${ }^{124}$

Despite the national drive towards economic prosperity that may ultimately leave indigenous land and resource rights marginalised, the Malaysian courts remain the last bastion of justice for Malaysia's indigenous minority peoples. In this sense, the role of the Malaysian judicia-

119. [2006] 1 MLJ 256, at 269.

120. TR Sandah FC [2017] 3 CLJ 1, at 68.

121. See above nn. 74-85 and accompanying text.

122. See K. McNeil, 'The Vulnerability of Indigenous Land Rights in Australia and Canada', 42 Osgoode Hall Law Journal 271 (2004).

123. See OSJ (2017), above n. 18, at 74-76.

124. Above n. 27, at 213. 
ry in protecting indigenous minority rights can function as a litmus test of whether the 'tyranny of the majority' prevails in Malaysia, a helpful scorecard for the practice of democracy. 